\title{
FACTORS INFLUENCING THE NUMBER OF BREEDING WATER BIRDS IN LAKE ENGURE, LATVIA
}

\author{
Jānis Vīksne, Māra Janaus, and Aivars Mednis \\ Institute of Biology, University of Latvia, Miera iela 3, Salaspils, LV-2169, LATVIA \\ E-mail: ornlab@ latnet.lv
}

Contributed by Jānis Vīksne

\begin{abstract}
Lake Engure has attracted great interest since the middle of the $19^{\text {th }}$ century when the water level of the lake was lowered by construction of a canal. The lake area decreased from $90 \mathrm{~km}^{2}$ to about $45 \mathrm{~km}^{2}$, and favourable conditions were created for development of emergent vegetation (presently covers $58.6 \%$ of area). A nature protection regime was established in 1957. The lake was included in the Important Bird Area list in 1994, in the Ramsar lists in 1995, and as part of the Natura 2000 network in 2004. The present paper deals mostly with data collected by the Laboratory of Ornithology, Institute of Biology, in the period 1948-2011. Direct and indirect impacts of climate, human activities, water level, vegetation succession, anthropogenic and natural food and predation on water birds (coot, waders, ducks, larids and grebes), as well as relationships between these water bird groups, were demonstrated. The impact of vegetation succession via overgrowing of meadows with reed and bushes, merging of the mosaic of small stands of emergents into huge reed dominated massives (thus reducing areas of habitats suitable for water birds) is described. The relation of Black-headed Gull population size with availability/unavailability of anthropogenic food and the associated changes in breeding duck numbers, as well as predation structure are discussed.
\end{abstract}

Key words: Engure Ramsar site, water birds, human impacts, anthropogenic food, vegetation succession, predation.

\section{INTRODUCTION}

The growing population of humans on Earth is having increasing impact on nature. The area of tropical rain forests is shrinking dramatically, and thus hundreds and thousands of species are becoming extinct before becoming known for science. The area of natural habitats in the temperate zone is also shrinking, due to land transformation to intensive agro-technical landscape and urbanized or industrialized environment, and more and more species are losing their habitat. Fortunately, there still are sites where nature and human activities coexist successfully and where humans can be considered as a component of ecosystem that does not have negative impact on other components. Not always has the role of humans been adequately examined in studies of natural ecosystems. Detailed investigation of interactions of human impacts and other components of ecosystems opens new opportunities in raising sustainability of economic activities. For these reasons, the international LTER (Long Term Ecological Research) Network project was modified into the LTSER (Long Term SocioEcological Research) Network, in which growing attention is paid to long-term investigations, Where human impacts are examined alongside interactions between organisms and their relationships with natural abiotic factors (Haberl et al., 2009). There are not many sites in which long-term ecological studies have been conducted. In Latvia, the catchment area of Lake Engure was chosen in 2010 as a LTSER region (Melecis, 2011). The area is outstanding in regard to the comparatively comprehensive and long-term investigations of different components of ecosystem. Ornithological studies allow to follow changes in avifauna of the lake and its surroundings since the end of the $19^{\text {th }}$ century, and particularly since the start of in-depth investigations of population ecology in 1958 (Löwis, 1898; Transehe, 1937; 1942; Kasparsons, 1960; Mihelsons, 1960; Виксне, 1968; Меднис, 1968; Михельсон и др., 1968; Блум, 1973; Михельсон и др., 1986; Vīksne, 1997; 2000; Vīksne et al., 2005; etc.). There is also a long history of investigations of the flora and vegetation (Kupffer, 1907; Спурис, 1960; Сабардина, 1968; Табака, 1974; 1977; Aunins et al., 2000; Gavrilova and Baroniņa, 2000; Laime, 2000), hydrobiology (Спурис, 1960; Вадзис и др., 1976; Springe et al., 1999; Sprinğge et al., 2000) and entomology (Спурис, 1962; Karpa, 2000; Melecis et al., 2000). Several of the conducted studies have utilized information on human activities in historical and present times (Transehe, 1937; 1942; Янаус, 1984; Vìksne, 1997) or have been experimental and targeted on improvement of conditions for breeding water birds (Михельсон, 1961; Mihelsons et al., 1976; Blums and Mednis, 1991; 
Janaus, 2002; Mednis, 2002a; 2002b; Opermanis, 2002; Vīksne un Laubergs 2007).

\section{SHORT HISTORY}

The Lake Engure lies near the western coast of the Gulf of Riga of the Baltic Sea. It developed about 4000 years ago from a lagoon of the ancient Littorina Sea (Bienenstamm, 1826; Eberhards and Saltupe 2000). In 1842, the water level in the lake was lowered by construction of a canal at its northern end, which drained into the sea (Ludwig, 1908; Transehe, 1942). In the following 170 years, the lake was known by its abundant eel Anguilla anguilla before 1928 (according to memories of local people) and its subsequent dramatic decline, richness of ducks in the hunting season, comparatively complete surveys of avifauna in the 1930s (Transehe, 1942), good fish catch and impressive growth of water bird populations during 1970-1990 (Blums et al., 1993; Viksne and Janaus, 1993), and rapid decrease in bird and fish resources during the last 15-20 years (Виксне и др., 2001). Ornithologists from the Institute of Biology (University of Latvia, formerly Academy of Sciences) have monitored changes in bird fauna of the lake since 1948, including stationary investigations since 1958 .

The investigations mentioned above have been conducted mainly on ducks, larids (especially Black-headed Gull Larus ridibundus), waders and Coot Fulica atra. Yearly counts have been made in rather big territories (for example, waders - up to 25 ha, ducks - up to 110 ha, larids the whole lake), and other monitoring has involved massscale ringing and re-trapping, marking of birds in feeding places with following controls in the lake, experiments with vegetation in nesting places, predation control, etc. The main results of these studies are published, and detailed description of study sites and corresponding field methods are given in those publications and will not be reviewed here (Mihelsons, 1960; Спурис, 1960; Михельсон и др., 1968; Виксне и Янаус, 1986; Vỉksne, 1997; etc.). Earlier work that has not published is reviewed in this article, as the data can be used to portray trends during the past 60 years, and be used to analyse interactions between species and their temporal changes. The trends can differ depending on the group of organisms studied. In the case of Lake Engure, the ongoing changes can be evaluated mainly regarding birds, as the richness and species diversity of birds has been the focus for establishing the nature protection regime (ornithological reserve) in 1957, Important Bird Area list in 1994, Ramsar convention site in 1995 and NATURA 2000 site in 2004.

\section{INTERACTION OF FACTORS}

To determine the influence of various factors on water birds, we considered ducks, larids, waders, grebes and coot. During the period of our investigations from 1948-2011, all species of these groups, except waders, have experienced an increase in population size followed by a decrease until today. The number of breeding waders on the lake in general has decreased during the whole study period. Among factors directly or indirectly influencing the population size of water birds, we analyzed the role of climate, humans, vegetation succession, water level, availability of natural and anthropogenic food, and predation (Fig, 1). Recognising that the impact of various factors and relations between different groups of organisms is quite schematic we nevertheless suppose that it can improve understanding of common effects in the ecosystem of the Lake Engure. The most important factors affecting water bird populations breeding in the Lake Engure can be considered to be climate and humans.

\section{CLIMATE}

The climatic changes since the last ice-age have had a dramatic impact on the tundra, taiga and mixed forest zones, including effects on plant and animal composition. Shallow lakes are particularly sensitive to climatic changes globally (Scheffer and van Nes, 2007). Development of Lake Engure ecosystem has been affected by changing climate and human impact over the past 8-9 thousand years (Eberhards and Saltupe 2000; Kalnina et al., 2011). Therefore, we consider "climate" together with "humans" to be the most im-

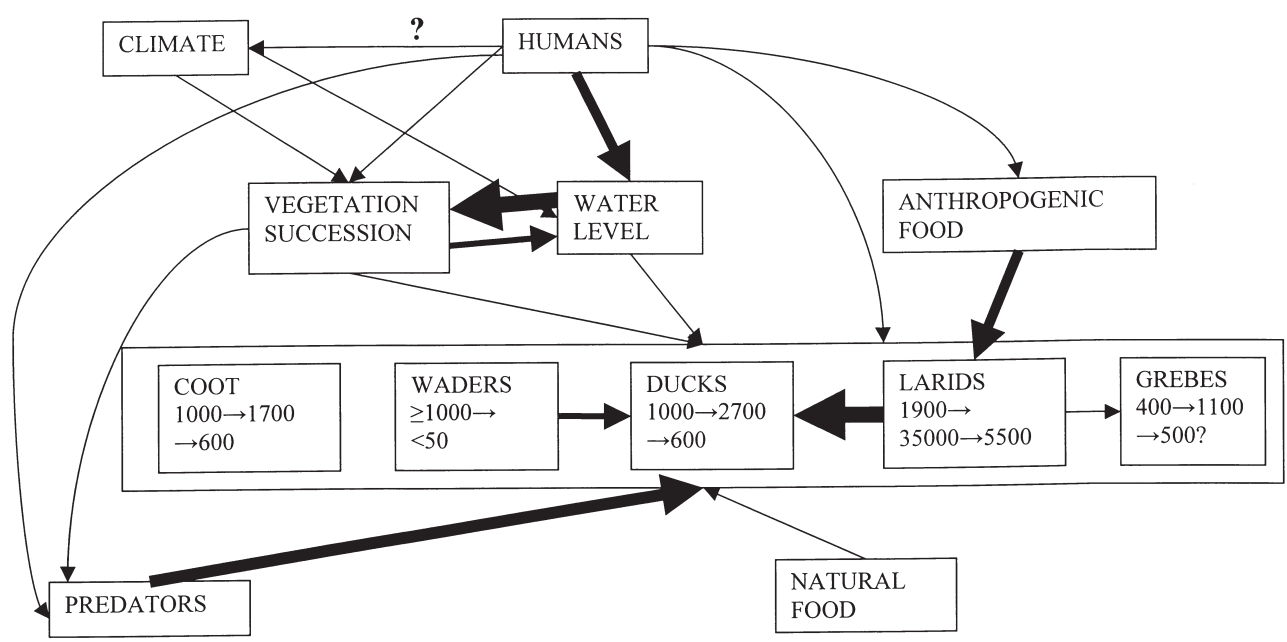

Fig. 1. Impact and relations between different factors and water birds on Lake Engure, Latvia. Numbers of breeding pairs are given under the names of water birds, at the beginning (1948-1960s), middle (1970s - very early 1990s) and end (early 1990s recent) of the study period (19482011) according to Mihelsons (1960), Blums et al. (1993), Vìksne (1997; 2000) and unpublished estimates by authors. 
portant factors influencing Lake Engure ecosystem. Unfortunately, in a comparatively short term, i.e. during 60 years of our observations, this influence is not so obvious without special detailed studies. The trend analysis of temperature series for the period 1970-2009 has shown a statistically significant increase of annual mean temperature (Spring ge et al., 2011).

Disappearance of several species of northern origin, as well as arrival and stabilisation of species of southern origin, in the lake's breeding bird fauna (Vīksne, 2000) can be explained by climate warming observed during recent decades. Shifts of breeding ranges of many bird species are expected due to climate warming in the future (Huntley et al., 2007). Other influences in the lake have mostly affected lake ecosystems indirectly, mainly via water level and vegetation succession (see respective chapters below).

\section{HUMANS}

The impact of humans on ecosystems is both direct and indirect. Fishing, hunting, cattle grazing on coasts and islands, reed cutting for roofs and other activities of humans have influenced the ecosystem of the lake long before 1842, when its water level was lowered by digging a canal to the sea at the northern end of the lake. The water level was lowered by approximately $1.5 \mathrm{~m}$, and the lake area decreased from 90 to 45 sq. km (Ludwig, 1908; Eberhards and Saltupe 2000). The former lake bottom was colonised by meadow vegetation and forest. Increase of shallow areas favoured development of both submerged and emergent vegetation. Also, natural processes of succession on coastal meadows and islands already from the very beginning were influenced by economic activities. Up until the middle of the $20^{\text {th }}$ century, meadow vegetation was maintained by mowing and grazing. In particular, mowing of the uniform mire sloughs in Grebis, Krievragsēklis, Kārklājs and some coastal territories need to be mentioned. Mowing of the unstable swaying mire was performed by scythe, and haystacks were placed on traditional raised constructions for this use. Hay was transported to farms in winter over ice. In mild winters, due to lack of ice, most of the prepared hay remained unused. This meadow land-use reduced reed spread and resulted in sedge-dominated meadows and haystack sites formed a network of dry ,islets" available during spring tide. Also, some hard surface islands or their forest-free parts (Lielā sala, Garrova, Akmeņrova, Lopsalrova) and grass meadows on the lake's western coast were mown regularly. In other areas, meadow vegetation was maintained by grazing - young stock and sheep on Lielrova, sheep on Kazrova, cattle and horses along the eastern coast. Up until 1957, mowing and grazing took place without any temporal, territorial or cattle density restrictions. Although this ensured meadow habitat in a large area, overgrazing or too early mowing was often observed in sites essential to birds, which led to lowered nesting success and decrease of breeding populations. Grazing and mowing of the lake's islands was banned in 1957, which resulted in a short-term increase in population size of nesting ducks and waders
(Mihelsons un Lejiņš, 1960; Михельсон, 1961). Development of emergent vegetation as well as submergent and floating plants undoubtedly was promoted by inflow of polluted agricultural waters. The effect of these waters nowadays can be assessed by spread of stands of water soldier Stratiotes aloides along the stream of River Dzedrupe from its mouth to the eastern end of the Island Liela. In the 1950s, water soldier was rare in the lake (Спурис, 1960).

Humans earlier had a great impact on the lake ecosystem (especially regarding Black-headed Gull) by vast amounts of anthropogenic food (organic waste) that was available around the lake (see below). The effect of humans on the lake ecosystem has also been direct by hunting of ducks, Coot and four geese species (up until 2004 also Common Snipe Gallinago gallinago and Moorhen Gallinula chloropus but their bag was insignificant). The total amount of shot water birds in the 1930s reached 2000-3000 individuals yearly, including 1500-2000 ducks (Transehe, 1937). The area was especially renowned for hunting of Mallard Anas platyrhynchos (Ërmanis, 1938). It is interesting that a similar number of yearly hunted ducks was registered also in 1953-1959 — average 1454 (range from 591 to 3097), daily bag - 0.8-1.8 ducks/hunter (Михельсон, 1961). Also in the 1970s and 1980s, the yearly bag constituted 15002000 ducks (Vìksne, 1997), the same amount as in the 1930s. However, it should be noted that the number of hunters in 1970s-1980s was several times higher than in 1930s. Nevertheless, the gradual growth of local breeding populations of Mallard, Shoveler, Pochard and Tufted Duck from the late 1950s till the early 1990s (Blums et al., 1993) confirms that there was no over-exploitation in the lake. Unfortunately, there are no data about number of harvested water birds during the whole hunting season in 1993-2008, but it is known that during the first three hunting times, in average 347 (153-593) birds, among them 205 (62-513) ducks and 142 (65-272) Coots were bagged each year (Vīksne, $2009 ;$ 2010). In recent years, there has been a decline in the numbers of hunters and (especially since 2007) bagged ducks. According to unpublished data of the Institute of $\mathrm{Bi}$ ology, the average number of hunters during the first hunting week in 2003-2006 was 206, and average number of hunted ducks was 222; in 2007-2011 - correspondingly 157 and 155.

Among other important direct impacts in the period up to the $20^{\text {th }}$ century, egg collecting (ducks, Coot, larids), and loss in fish nets as bycatch (which is still an issue today) need to be noted. Fishing technologies have changed over time. In the 1950s-1970s, mostly fish-baskets were used, while starting in the 1990s only nets have been used. These methods differ in bycatch amounts - very little in baskets, common in nets (Spalis, 1999).

Predators have suffered both by direct and indirect impact by humans as well (see also below). It was generally considered in the $19^{\text {th }}$ and first half of the $20^{\text {th }}$ century that avian raptors there had a negative impact on other birds in Lake Engure. As a result of this conception, populations of White-tailed Eagle Haliaeetus albicilla, Spotted Eagle 
Aquila clanga, Osprey Pandion haliaetus and Eagle Owl Bubo bubo suffered in the first half of the $20^{\text {th }}$ century due to shooting. Also, the low numbers of the Marsh Harrier Circus aeruginosus in the lake in the 1950s (5-10 pairs; Mihelsons, 1960) can also be explained by widespread culling. Occasional shooting of corvids practically did not influence populations of these species. Issues related to predation are described in more detail in the chapter "Predation".

The most serious impact on the lake ecosystem was by willing or unwilling introduction of two alien species (American mink Mustela vison and Ussurian raccoon dog Nyctereutes procyonoides) in the fauna of Latvia (Tauriņ̌s, 1984). The impact on water bird populations by these mammals was a direct consequences of human activities.

Nature protection measures can also be considered as human impact, as establishment of a nature (ornithological) reserve in the lake area in 1957 affected the ecosystem. In 1957, the lake was completely closed for economic and recreational activities during bird breeding season. Later, from June 20 to mid-August only shallow water areas rich in emergent vegetation were closed, and even later, fishing and hunting (mid-August - November) was allowed in the whole lake, except in ca. 1000 ha which remained closed during the whole ice-free period. Regulation of economic and recreational activities at temporal and spatial scales, as well as limitation in exploitation of particular species (groups of species) to some degree had effects. Nature protection management in the Lake Engure area has shown that specific types of economic activities, such as cattle grazing, hay-making and reed-cutting, require regulation, but that they must be continued to maintain habitats important for birds. Another type of human activity is habitat management targeted to improvement of quality for water birds. This type of management in the central part of the lake has been carried out since the 1960s, by creation of artificial islands (at lower-lying parts of natural islands not suitable for nesting), maintaining and restoring suitable vegetation, and predator control. These time-consuming measures have resulted in increasing of water-bird populations (Михельсон, 1961; Mihelsons et al., 1976; Blums and Mednis, 1991; Opermanis, 2002; Janaus, 2002; Mednis, 2002a; 2002b; Vīksne un Laubergs, 2007). The management and seasonal restriction measures applied in Lake Engure in 1958-1993 resulted in high (about 70\%) and increasing $(P<0.05)$ average unweighted apparent nesting success of ducks (all species combined), increase of their breeding population, and increase of adult female survival rate (Blums et al., 1993). It should be stressed that the results mentioned above were achieved in a relatively small area (about one third of the lake area, ca. 15 sq.km).

Although two management plans for Lake Engure Nature Park have been adopted (1999-2008, 2011 onwards), which prescribe different types of habitat management, due to insufficient funding these human activities recently have very limited effects to lake's ecosystem.

\section{WATER LEVEL}

In 1842, the water level of Lake Engure was lowered by 1.5 $\mathrm{m}$, which drastically changed conditions in the lake and in its surroundings. During the sixty years after lowering of the water level (Ludwig, 1908), the area of wet meadow significantly increased on the western coast, the sandy eastern coast attracted attention of humans due to a large amount of amber (Kawall, 1853), colonisation by pine forest occurred, and rich emergent vegetation developed in shallow water areas, e.g. at northern and southern ends and along the western coast, especially between the rivers Skujupe and Dzedrupe, etc. (Ludwig, 1908). Subsequent changes related to lowering of the water level were described by Transehe (1937; 1942), Vīksne (1997).

Water level in Lake Engure has been recorded since 1970 by the Institute of Biology (unpublished). Aerial photos (1956, 1972, 1981 - archives of Institute of Biology) and ortophoto maps $(1994,2004,2007)$ have shown that a lake depth $<0.5 \mathrm{~m}$ is most suitable for the development of emergent vegetation (Brižs, 2011). During 1956-2007, the surface area of emergent vegetation increased from $30 \%$ to $58.6 \%$ in the lake. The increase in overgrown territories has not taken place evenly, and has been more rapid during periods of lower spring tide and vice versa. The increase in emergent vegetation has been more rapid in 1956-1972 and considerably slower in 1972-2007.

Development of emergent vegetation is not a linear process, and in some locations a reduction has taken place. A decrease in area of emergent vegetation is favoured by high water level and no ice cover in November, December and even in January, particularly when these events have occurred for several years. In these years, storms tear emergent vegetation mats up from the bottom sediments and cast them ashore. Ability to withstand high wind and high water level depends on the stand size: larger stands with diameter about $200 \mathrm{~m}$ are not much affected while smaller ones are torn away and driven ashore or merge with larger stands. Such removal of smaller stands can be caused also by high spring flood, most often, by moving ice, as occurred in spring 2011 (unpublished data of the Institute of Biology).

As mentioned above, decrease in water level promotes increase in emergent vegetation area. Our recent (2009-2011) observations showed that intensive vegetation growth can also promote increase of water level, as it hinders outflow. As a result, the spring flood falls slowly and many duck and wader nesting sites remain flooded throughout the season. Under such conditions, also the area suitable for feeding dabbling ducks decreases, as well as the number of moulting dabbling ducks on the lake (unpublished data of Institute of Biology).

\section{VEGETATION SUCCESSION}

Successional change of vegetation is the main factor determining habitat conditions for different birds. As mentioned above, the successional processes have been influenced 
both by natural and anthropogenic factors. Climate warming and man have promoted overgrowing, the latter mainly by means of changing water level, hydrological regime, and pollutants (Wetzel, 1983). We have already mentioned that healthy stands of water soldier developed along the River Dzedrupe water flow in the lake, while this species was very rare in the 1950s (Спурис, 1960). Unfortunately, there are no data on concentrations of biogenic elements before 1995. Since 1995, no major changes have been observed in concentrations of biogenic elements (Sprinğge et al., 2011). For water birds, the most important habitats are (1) coastal, island and slough areas covered with meadow vegetation, and (2) emergent vegetation.

After lowering of the lake water level, meadow vegetation along coasts and on islands as well as on mires, was maintained by grazing and cutting. These areas were typically invaded by waders and ducks. The majority of wader species prefer low, medium density vegetation, while most duck species prefer a denser one or a level with a sparse second level of grass or sedge vegetation (Меднис, 1968; Сабардина, 1968). Our long-term observations showed that cessation of mowing and/or grazing triggered growth of forest, osiers Salix sp. and reed (depending on site's humidity) and that the areas gradually became unsuitable for nesting of ducks, waders and gulls (Vìksne, 1997).

Successional changes of emergent vegetation, observed by researchers on the lake, have affected both species composition and structure and the total area of stands. This is the crucial factor determining suitability of the lake for different bird groups. The changes of emergent vegetation occurred in the following stages:

1. Mosaic of small, unispecies or mixed stands that are rooted in bottom sediments where open water area is larger than the total vegetation stand area. Mainly reed Phragmites australis, narrow leaved cattail Typha angustifolia, bur-reed Sparganium sp., horsetails Equisetum sp. and bulrush Scirpus lacustris form the stands. Bird species that build floating or partly floating nests are most common in these areas - grebes (Great Crested Podiceps cristatus, Rednecked Podiceps grisegena, Slavonian Podiceps auritus), Coot, Black Tern Chlidonias niger, Little Gull Larus minutus, and Black-headed Gull.

2. Emergent vegetation - open water mosaic remains, but area of open water now is smaller. The small stands meet and merge and narrow leaved cattail-dominated sloughs with patches of reed, broad leaved cattail Typha latifolia, sedge Carex sp., bittersweet Solanum dulcamara appear. The sloughs provide substrate dry enough for nesting of gulls (predominantly Black-headed Gull) and different duck species (Tufted Duck Aythya fuligula, Pochard Aythya ferina, Mallard, less often Shoveler Anas clypeata, Gadwall Anas strepera, Garganey Anas querquedula and Pintail Anas acuta). Ducks, Coot, gulls and terns prefer nest sites in the vicinity of open water - along margins of the slough or in inner lagoons. Number of breeding water birds peaks when the borderline between open water and the compara- tively dry sloughs is the longest (unpublished data). Grebes and Coot continue to breed in the sparser vegetation in the periphery of stands.

3. Sloughs merge, forming large (hundred to several hundred meters diameter) reed-dominated tracts with narrow leaved cattail remaining only in some places, such as a narrow belt in the outside part of the stand. Length of the border between dry slough substrate and open water decreases drastically. The slough becomes dryer allowing invasion of osiers, birch trees Betula sp. and alder Alnus species. The slough becomes suitable for permanent presence of American mink and raccoon dog. During this successional stage, birds characteristic of emergent vegetation habitat, such as grebes, coot, gulls, terns and ducks, breed in low numbers, and only in a narrow belt in the outskirts of the emergent vegetation tracts. Black-headed Gull and other larids move to sparse narrow leaved cattail stands, as far as possible from the large reed tracts. There they build nests on floating cattail rhizomes. Unfortunately, very few ducks are able to find sufficiently dry sites for nesting.

On islands and in the coastal areas, successional vegetation development occurs as gradual overgrowth of meadow vegetation (previously maintained by regular mowing and grazing) with reed, bushes and trees. This results in habitat loss for waders, gulls and terns and almost all duck species. Overgrowing of islands provides suitable conditions for permanent presence of raccoon dog and fox, which is an additional factor causing water bird extinction.

\section{ANTHROPOGENIC FOOD}

Anthropogenic food in context of Lake Engure can be considered as an example how human activities, even several tens of kilometres from the lake, can became a powerful factor influencing not only species directly, but also can affect the whole ecosystem of the lake.

Anthropogenic food has particularly affected the Blackheaded Gull population. The breeding population of this bird in the lake was estimated as 170-230 pairs in 1949 (Mihelsons, 1960) and reached 34000 pairs in 1986 (Vīksne and Janaus, 1989). A dramatic decrease to only 4200 pairs occurred by 2002 (Vīksne et al., 2005), which stabilized to about 6100 pairs in later years. The growth of number of Black-headed Gull was promoted by different factors, including establishment of a protection regime on the lake in 1957. However, the main reason was change in food selection of the species to anthropogenic food, starting around the beginning of the 1960s, which coincided with abundant offer of this food. Feeding in fishing locations and fish harbours along the Gulf of Riga was characteristic for Black-headed Gulls from Lake Engure over a long period of time, but due to increasing amount of catch and mismanagement of the caught fish (durable display without cover), food availability to gulls increased. After implementation of fishing restrictions in the Gulf of Riga in 1971, Blackheaded Gulls from Lake Engure began feeding flights in- 
land to agricultural lands and refuse dumps up to $40 \mathrm{~km}$ from the lake, which was not characteristic of them previously. The second source of anthropogenic food along the seashore was fish canneries, where smoked sprat heads (remnants of canned sprats) and other fish production waste was available for gulls. Feeding flights along the seashore to fish canneries reached $65 \mathrm{~km}$ (Виксне и Янаус, 1986).

Another source of anthropogenic food to the gulls was the Lubezere mink farm, located about $40 \mathrm{~km}$ from the lake. In this farm, tens of thousands animals were fed twice a day. As a rule, a part of the food was not consumed and before the next feeding was pushed to the ground where it was collected by gulls. This food was well balanced according to composition, nutritious, and continuously available. Abundance of anthropogenic food resulted in a high survival rate of chicks (Виксне, 1981). The change of the socio-economic system at the beginning of 1990s rapidly decreased the availability of anthropogenic food, due to economic incentives to decrease waste and losses in the now privatised fishing fleet and fish canneries. In mink farms, animals were now fed only once a day, and unconsumed food was collected. Many mink farms, including the Lubezere farm which affected Engure bird populations, were closed.

The reduction of the population size of Black-headed Gull by 8.5 times was not exclusively related to availability of anthropogenic food, as growth of the American mink population also had an effect on this species as well as on ducks and other water birds (see above).

Feeding of the Black-headed Gull outside the lake also affected water quality. The maximum number of breeding Black-headed Gulls was 34000 pairs, equal to 68000 adults, and approximately the same number of young. These individuals obtained food outside of the lake area, but deposited excrement in the lake. Although there have been few studies on pollution of this type in Lake Engure (Briede et al. 2000), this effect may explain the comparatively high concentration of nutrients and disappearance of, for example, Characeae algae in a zone several to even $100 \mathrm{~m}$ around big (thousands of pairs) long-term breeding colonies of these gulls (unpublished data).

\section{INTERRELATIONS AMONG DIFFERENT GROUPS OF WATER BIRDS}

Larids — gulls and terns - are a group of species the presence of which, the species composition and numbers are relevant for other water birds and the whole ecosystem of the lake.

The breeding density of ducks in larid colonies, as well as their breeding success, is much higher than outside the colonies, and a colony serves as a signal of a safe nesting site (Koskimies, 1957; Hilden, 1964; Bergman, 1982; Vīksne et al., 2000). However, colonies of greater gulls can become an ecological trap for ducks due to predation by these gulls on ducklings (Vermeer, 1968; Dwernychuk and Boag 1972). There are no colonies of these big gulls (for example, Herring Gull Larus argentatus) in Engure, and ducks breed in colonies of Common Tern Sterna hirundo and (mainly) Black-headed Gull, which also have been observed to kill ducklings, but only in particular cases. In a long-term study (1960-1994), colonies of Black-headed Gull were shown to be high quality nesting places, as mass of incubating females of Pochard, survival and breeding success were higher in colonies in comparison with nesting areas outside colonies (Blums et al., 2003a). First year survival of ducklings hatched in and outside colonies was similar, which indicated insignificant loss of ducklings in Black-headed Gull colonies due to attacks, or reduction of some other mortality factor (Blums et al., 2003b). This study on Pochard can clearly be extrapolated to other duck species nesting in colonies of Black-headed Gull.

The habitat preference of duck species to nest in Blackheaded Gull colonies changed over time. At the beginning of our studies at the turn of the 1950s-1960s, a pronounced preference to nest in these colonies was observed only for Tufted Duck (Михельсон и др., 1968), but at the end of 1980s Pochard and Mallard also preperred gull colonies (Виксне и др. 1989). Grebes (Great Crested Grebe, Rednecked Grebe, also Slavonian Grebe) also prefer to use Black-headed Gull colonies as nesting places. Ducks choose to nest not only in colonies of Black-headed Gull and other larids, but also in wader communities (Mihelsons un Lejiņš, 1960; Михельсон, 1961). This can clearly be explained by active defence by several wader species (Black-tailed Godwit Limosa limosa, Lapwing Vanellus vanellus and Redshank Tringa toetanus) against nest predators.

The rapid decline of Black-headed Gull in the 1990s was associated also with a change of colony location to avoid American mink. Gulls have abandoned relatively dry emergent vegetation areas suitable for nesting and moved as far as possible from these areas to sparse narrow-leaved cattail stands which are not much used by American mink, and are not very suitable for nesting of ducks. In such areas, only grebes utilize larid colonies for nesting.

Coot, a common water bird of the lake, is a territorial species that demonstrates aggressiveness to other bird species in its territory. However, studies performed in Lake Engure showed that this aggressiveness has not affected densities of ducks and other water birds, neither in studied plots nor in the whole lake (Блум, 1973).

Finally, regarding interactions between water birds, also Cormorant Phalacrocorax carbo should be considered. The first breeding attempt of this species in the lake was recorded in 1990, but in 2011 the local breeding population was already estimated as 150 pairs, and the number of non-breeders was about 500 specimens (unpublished data). A negative impact of Cormorant on other water birds has been shown in cases when both nesting and non-breeding birds occupy sites of breeding colonies of Black-headed Gull or Common Tern, which are ideal also for duck nest- 
ing. Gulls and terns, and also ducks, abandon Cormorant areas. Cormorants might compete with other fish-eating birds (Grey Heron Ardea cinerea, grebes etc.), but special studies are required to confirm this.

\section{PREDATION}

Predators are an essential component of ecosystems. On Lake Engure, eight mammalian and nine bird species can be considered as predators of eggs, incubating specimens and unfledged young (Table 1). The group of most dangerous predators includes mammals - Ussurian raccoon-dog, American mink and red fox, and birds - Marsh Harrier, Hooded Crow Corvus corone cornix and Raven Corvus corax. Studies performed in 1985-1997 (Opermanis et al., 2001) showed that these predators include both generalists that destroy nests of various ducks and larids (for example, Marsh Harrier) and those preferring specific species during nesting period of prey (Raven, Hooded Crow - early nesting Mallards) or due to prey size (American mink - comparatively smaller Garganeys, Shovelers, Gadwalls and Tufted Ducks). Compensatory predation was suggested in cases of high nesting density — predation by Marsh Harrier increased after a decrease in the number of American mink (Opermanis et al. 2001; 2005).

The structure of predation changed during our study period: at the beginning predation by corvids (Hooded Crow and

Table 1

DEPREDATION OF MAMMALS AND BIRDS ON WATERBIRD ADULTS, CLUTCHES AND CHICKS ON LAKE ENGURE, LATVIA, 1958-2010

\begin{tabular}{|c|c|c|c|}
\hline \multirow[t]{2}{*}{ Species } & \multicolumn{3}{|c|}{ Depredate on } \\
\hline & adults & clutches & chicks \\
\hline \multicolumn{4}{|l|}{ Most important predators } \\
\hline Red fox Vulpes vulpes & + & + & + \\
\hline Raccoon dog Nyctereutes procyonoides & $?$ & +++ & ++ \\
\hline American mink Mustela vison & +++ & ++ & +++ \\
\hline Marsh Harrier Circus aeruginosus & + & +++ & ++ \\
\hline Raven Corvus corax & - & +++ & + \\
\hline Hooded Crow Corvus corone cornix & - & +++ & + \\
\hline \multicolumn{4}{|l|}{ Less important predators } \\
\hline Wild boar Sus scrofa & - & + & + \\
\hline Otter Lutra lutra* & $?$ & ? & $?$ \\
\hline Stoat Mustela erminea & - & + & + \\
\hline Polecat Mustela putorius* & $?$ & $?$ & $?$ \\
\hline Norway rat Rattus norvegicus $* *$ & - & + & $?$ \\
\hline White-tailed Eagle Haliaeetus albicilla & + & $?$ & $?$ \\
\hline Mantagu's Harrier Circus pygargus & - & + & + \\
\hline Goshawk Accipiter gentilis & + & $?$ & $?$ \\
\hline Spotted Eagle Aquila clanga & $?$ & + & + \\
\hline Eagle Owl Bubo bubo & + & - & $?$ \\
\hline Magpie Pica pica & - & ++ & + \\
\hline
\end{tabular}

Raven) and Marsh Harrier dominated, but this gradually switched to mammalian predation via spread of raccoon dog and American mink (Table 2). The predation structure is to a great extent affected by humans. The large number of Ravens (several tens of big flocks of immature birds) was related to features of the economy of the socialism system open garbage places, including fallen livestock. Two predators - Ussurian raccoon-dog and American mink - are alien species: the raccoon dog was purposely introduced in 1948 (Tauriňš, 1984) and the wild population of American mink expanded from animals that escaped from mink farms at the turn of the 1960-1970s, and the population is still supplementing in this way. To complete the view of influence of raptors on waterbirds, the "surplus killing" by this predator often observed in Latvia should be mentioned as well. It means killing of a large number of breeding adults (duck females, Black-headed Gull, Common Tern) and young larids, for example, Herring Gull, without consuming them. For example, one mink female, in a period of approximately ten days before digging her den, with still blind cubs, killed at least 40 adult Black-headed Gulls, five breeding duck females and one gosling (Vīksne, 1997).

During recent decades, the number of mammalian predators — red fox and raccoon dog — has increased considerably, possibly due to increase of area of suitable habitats and also rabies oral vaccination, which was intensively carried out since 2005 by distributing vaccine bait from planes (Oḷševskis and Liepiņš, 2010). Vaccination can cause a short-term increase of the predator populations (Bellebaum, 2003).

The structure of predation undoubtedly is influenced by succession of emergent vegetation on the lake. The overgrowing of territories by uniform stands of emergent plants and drying out of sloughs allowed raccoon dog and red fox to reach breeding islands of water birds situated quite far from the coast, by swimming and wading. The effect of presence of predatory mammals on breeding water birds is shown in Figure 2. On Lielrova Island (10.6 ha), where 335 duck nests (68\% successful) were found in 1993, only six ducks (one successful) were recorded in 2009, and two (both unsuccessful) in 2010. The explanation for this disappearance of breeding ducks was predation. During nest counts of water birds in 2007, one family of raccoon dog (both adults and nine cubs, all eliminated) was found, in 2008 one fox family outside its den in a reed stack (two cubs eliminated) was found, in 2009 a raccoon dog female in lactation was shot (29.04.), and in 2010 - persistent presence of fox was noted early in spring.

After mass-scale nest damage, even if only clutches and young were affected, the restoration of a breeding population in that area (island) occurs very slowly. The island becomes less suitable also for predators. For example, since 1999, on island Kazrova after heavy predation (all ten duck nests depredated), the number of breeding ducks decreased dramatically, and recovered very slowly (12 duck nests in 2010), even when also gulls and terns had returned for breeding (unpublished data of the Institute of Biology). 
CHANGES OF MOST COMMON DUCK NEST PREDATOR ACTIVITIES (NUMBER OF DEPREDATED NESTS) ON ISLANDS OF LAKE ENGURE, 1959-2009

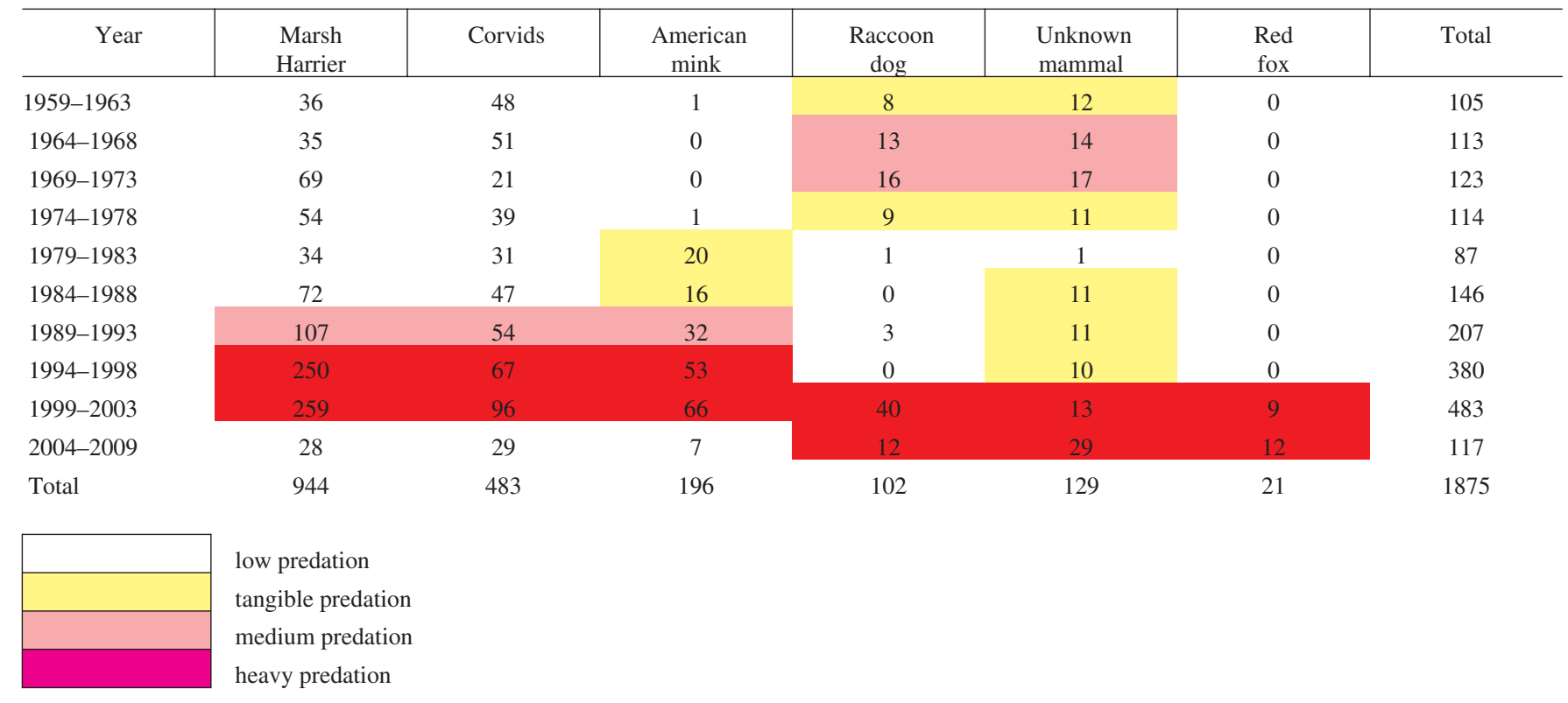

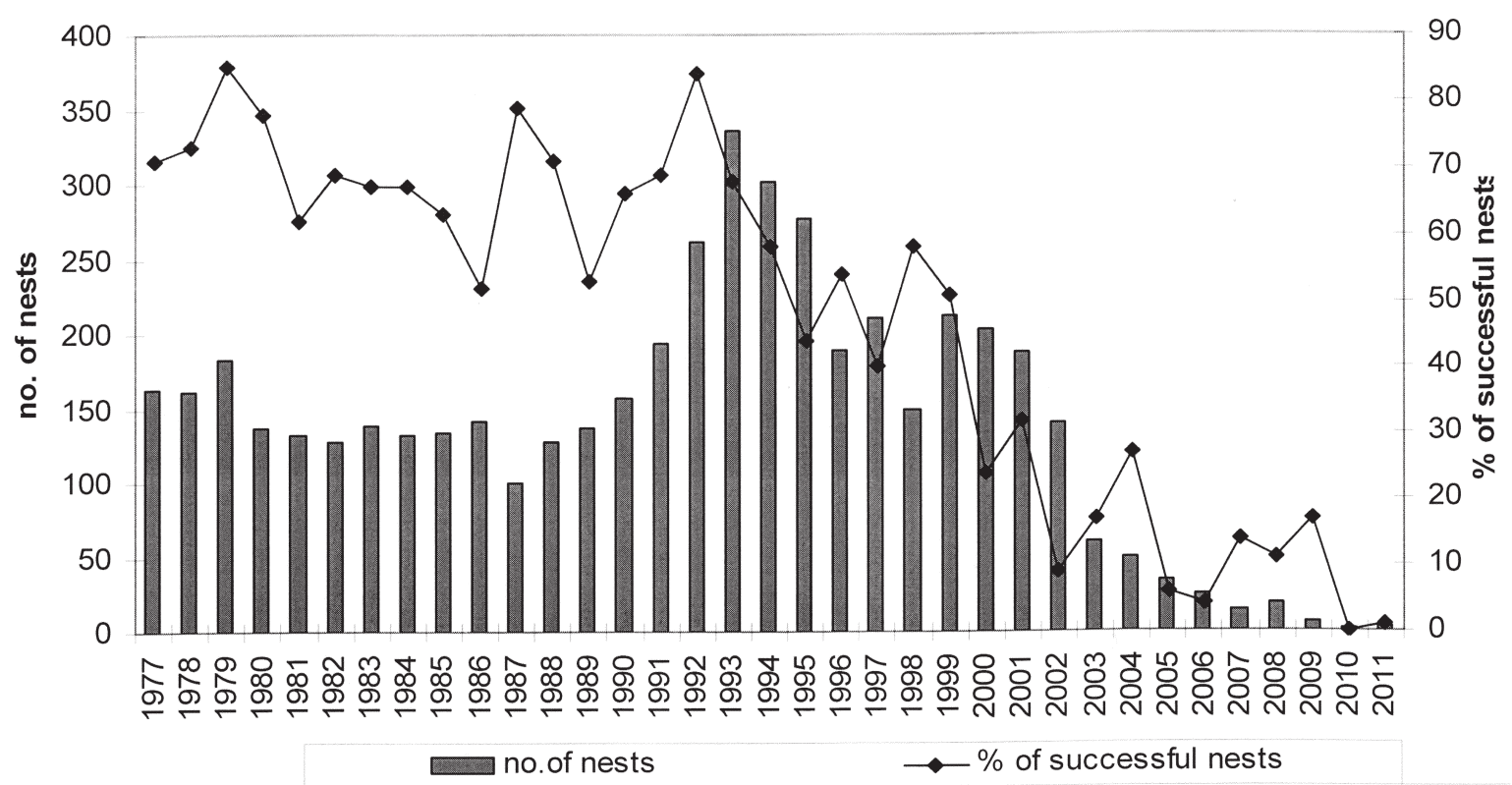

Fig. 2. Number of duck nests and percent of successful nests on Island Lielrova, Lake Engure, in 1977-2011.

\section{NATURAL FOOD}

Although the lake's biodiversity, including natural food for water birds, is extremely rich, it is clear that food resources also changed, affecting water birds feeding in or near the lake. Unfortunately, in Engure food composition of water birds as well as their dynamics over the years has been studied insufficiently. Available data on biomass of macrozoobenthos in 1958-1959 (Спурис, 1960), in 1964 (Вадзис и др., 1976) and in 1995-1999 (Sprinǵe et al., 2000) do not show any trends that could have an impact on water bird life conditions, but this may be due to different sampling methods. More detailed data are necessary on feeding habits of birds in the lake, and on specific groups of benthos organisms, their abundance and availability to various consumers.

\section{CONCLUSIONS}

Studies on Lake Engure ecosystems during the last 60 years and earlier indicate complicated relations between different groups of water birds and their relations to various biotic and abiotic factors.

The influence of climate is well known; it has affected lake ecosystem by raised temperature and water level, which led 
to changing conditions for plants and animals. During our observation period (1948-2011), all groups of studied water birds except waders experienced population growth at the beginning of the period, achieved maximum population size in the middle of this period, and declined later. The number of waders declined during the whole observation period. The main reasons for these local declines were decrease of area of suitable habitats due to overgrowing of meadows with reed and shrubs, change of structure of emergent vegetation due to merging of small stands and forming of huge reed-dominated massives.

Human impacts have been surprisingly diverse: decline of lake water level promoted overgrowing and economic activities (grazing, mowing) maintained permanent meadow vegetation on coastal areas and islands for a period of nearly 100 years. Humans introduced two alien mammal predators - Ussurian raccoon dog and American mink in the Latvian fauna, which drastically worsened life conditions for water birds. The consequences of providing nearly unlimited availability of anthropogenic food for Black-headed Gull in fish harbours, canneries and mink farms were surprisingly far-reaching. The population size of Black-headed Gull increased from 170 to 34000 pairs, and of various duck species from 1000 to 2700 pairs. Change of the socioeconomic system in the early 1990s resulted in a major decline of availability of anthropogenic food for Black-headed Gull, which caused decline of their numbers to 4100 pairs (i.e. about eight times), and decline in ducks to 600 pairs (i.e. 4.5 times). This process was promoted also by predation by mammals (red fox, raccoon dog, and American mink) in nesting areas of water birds. The role of larids needs to be stressed, especially regarding the relations of Black-headed Gull with various groups of water birds. Presence of larids and some waders serves as a signal for ducks that the area is a good nesting place, which will ensure higher nesting success (if mammal predation is lacking). However, the probability of nesting failure for ducks increases in cases where a mammalian predator is present in a high-density gull colony (unpublished data of the Institute of Biology).

Regarding the future of Lake Engure as a nature protection territory of international importance, it seems clear that management is needed to prevent further decline of water bird species and population size. Needed measures include maintaining of meadow vegetation by grazing, fragmentation of emergent vegetation, predation control, and regulation of water level corresponding to needs of water birds. Also, monitoring of water bird breeding populations and harvested waterfowl is needed, as well as intensified studies on water bird feeding habits and their food sources.

\section{ACKNOWLEDGEMENTS}

This long-term study became possible due to support from the State budget to the Institute of Biology, and by the grant 09.1346 and cooperation project 10.0004.1.5. After re-establishing of Latvian independence, studies at Engure regu- larly were supported also by different international (OMPO - Migratory Birds of the Western Palearctic) and national organizations (Ministry of Environment, and Latvian Hunting Management Development Fund) as contract projects. We are very much obliged to all these organizations as well as to all field work participants. As the paper deals with data collected during mote than 60 years, it is impossible to mention all contributing persons in a few lines. But we remember and appreciate all helpful hands at Engure.

\section{REFERENCES}

Auniņš, A., Zviedre, E., Brūmelis, G. (2000). Preliminary results of remote sensing based vegetation mapping of Lake Engures (Engure), Latvia. Proc. Latvian Acad. Sci. Sect. B, 5/6, 170-176.

Bellebaum, J. (2003). Bestandsentwicklung des Fuchses in Ostdeutschland vor und nach der Tollwutimpfung. Jagdwiss., 49, 41-49.

Bergman, G. (1982). Inter-relationships between ducks and gulls. In: Proceedings of the $3^{\text {rd }}$ Technical Meeting on Western Palearctic Migratory Bird Management (pp. 241-247). Scott, D.A. (ed.). International Waterfowl Reserch Bureau Slimbridge.

Bienenstamm, H. von. (1826). Geographischer Abriss der drei deutschen Ostsee-Provinzen Russlands. Riga.

Blums, P., Bauga, I., Leja, P., Mednis, A. (1993). Breeding population of ducks on Engure Lake, Latvia, for 35 years. Ring, 15(1-2), 165-169.

Blums, P., Mednis, A. (1991). Management of islands for breeding waterfowl on Engure Marsh, Latvia. In: Wetland management and restoration Proceedings of Workshop, Sweden, 1990 (pp. 128-134). Finlayson, C.M., Larsson, T. (eds.). Solna.

Blums, P., Nichols, J.D., Lindberg, M.S., Hines, J.E., Mednis, A. (2003a). Factors affecting breeding dispersal of European ducks on Engure Marsh, Latvia. J. Animal Ecol., 72, 292-307.

Blums, P., Nichols, J.D., Hines, J.E., Lindberg, M.S., Mednis, A. (2003b). Estimating natal dispersal movement rates of female European ducks with multistate modelling. J. Animal Ecol., 72, 1027-1042.

Briede, A., Kḷaviņš, M., Rodinovs, V. (2000). Chemical composition of Lake Engures (Engure), Latvia. Proc. Latvian Acad. Sci., Section B, 54(5/6), $160-163$.

Brižs, J. (2011). Dynamics of emergent macrophytes for a half century in coastal Lake Engure, Latvia. Proc. Latvian Acad. Sci., Section B, 65(5/6).

Dwernychuk, L.W., Boag, D.A. (1972). Ducks nesting in association with gulls - an ecological trap? Can. J. Zool., 50, 559-563.

Eberhards, G., Saltupe, B. (2000). Geological history, relief and deposits of Lake Engures (Engure) area along the Baltic Sea. Proc. Latvian Acad. Sci., Sect. B, No. 5/6, 141-147.

Ērmanis, J. (1938). Šis un tas par Engures ezeru un tā apkārtni [This and that about the Lake Engure and its surroundings]. Medn. Makšk,., 9, 352.-354. 1pp. (in Latvian).

Gavrilova, G,., Baroniņa, V. (2000). Vascular plant flora of the Lake Engures (Engure) drainage basin, Latvia, and the coastal zone of the Gulf of Riga. Proc. Latvian Acad. Sci. Sect. B, 5/6, 177-189.

Huntley, B., Green, R., Collingham, Y., Willis, S.G. (2007). A Climatic Atlas of European Breeding Birds. Lynx Edition. 521 pp.

Haberl, H., Gaube, V., Diaz-Delgado, R., Krauze, K., Neuner, A., Peterseil, J., Plutzar, Ch., Singh, S.J., Vadineanu, A. (2009). Towards an integrated model of socioeconomic biodiversity drivers, pressures and impacts. A feasibility study based on three European long-term socio-ecological research platforms. Ecol. Econ., 68, 1797-1812.

Hilden, O. (1964). Ecology of duck populations in the island group of Valassaaret, Gulf of Bothnia. Ann. Zool., 1, 153-277. 
Janaus, M. (2002). Mākslīgo salu veidošana ūdensputnu ligzdošanai [Creation of artificial islands for breeding waterfowl]. Grām.: Aktuāli savvaḷas sugu un biotopu apsaimniekošanas piemēri Latvijā (74.-80. lpp.). Rīga (in Latvian)

Kalniņa, L., Grudzinska, I., Stivriņš, N. (2011). Engures ezera nogulumu pētījumi un tā attīstības rekonstrukcija [Studies of sediment in Lake Engure and reconstruction of lake's development]. Geogräfija, Geologija, Vides zinātne. Referātu tēzes. Rīga. Latvijas Universitāte. 208. 1pp. (in Latvian).

Karpa, A. (2000). Flies (Diptera, Brachycera) of the Lake Engures (Engure) Nature Park. Proc. Latvian Acad. Sci. Sect. B, 5/6, 203-212.

Kasparsons, G̣. (1960). Niedru lijas (Circus aeruginosus) barošanās Engures ezerā 1958. gada vasarā [The feeding habits of the Marsh Harrier (Circus aeruginosus) on the Lake Engure during summer 1958]. Grām.: Latvijas риtпu dzìve (45.-51. lpp.). Rìga (in Latvian).

Kawall, H. (1853). Der Bernsteinsee in Kurland. Korrespondenzblatt Naturf.-Ver. Riga, Nr. 6, 69-71.

Koskimies, J. (1957). Terns and gulls as features of habitat recognition for birds nesting in their colonies. Ornis Fennica, 34(1), 1-6.

Kupffer, K.R. (1907). Kleine Notizen. Korrespondenzblatt des Naturforscher-Vereins zu Riga, 50, 180-210.

Laime, B. (2000). Seashore plant communities of the Lake Engures (Engure) Nature Park, Latvia. Proc. Latvian Acad. Sci. Sect. B, 5/6, 190-196.

Löwis, O.v. (1898). Notizen aus den baltischen Provinzen. Ornith. Monatsber., 6(12), 196-198.

Ludwig, F. (1908). Die Küstenseen des Rigaer Meerbusens. Arbeiten des Naturforscher-Vereins zu Riga. Neue Folge. Heft 11. 197 S.

Mednis, A. (2002a). Amerikas ūdele ūdensputnu ligzdošanas vietās: kā ar to cīnīties [American mink in waterfowl breeding areas: How to control it's numbers]? Grām.: Aktuāli savvaḷas sugu un biotopu apsaimniekošanas piemēri Latvijā (57.-61. lpp.). Rīga (in Latvian).

Mednis, A. (2002b). Niedru pḷaušanas ietekme uz ligzdojošo ūdensputnu skaitu [Effects of reed cutting on numbers of breeding waterfowl]. Grām.: Aktuāli savvaḷas sugu un biotopu apsaimniekošanas piemēri Latvijā (81.-87. lpp.). Rīga (in Latvian).

Melecis, V. (2011). Ilgtermiṇa socioekoloğiskie pētījumi: izaicinājumi un problēmas [Long-term socioecological research: Challanges and problems]. LU 69. zinātniskā konference. Geogrāfija. Geologija. Vides zinātne (458.-459. 1pp.). Referātu tēzes. Rīga (in Latvian).

Melecis, V., Karpa, A., Spungis, V. (2000). Assesment of the strategy used for insect population monitoring in the Lake Engures (Engure) Nature Park, Latvia. Proc. Latvian Acad. Sci. Sect. B, 5/6, 197-202.

Mihelsons, H. (1960). Engures ezera putnu fauna [The birds of the Lake Engure]. Grām.: Latvijas putnu dzīve (5.-44. 1pp.). Rīga (in Latvian).

Mihelsons, H., Lejiṇš, G. (1960). Novērojumi par medību ūdensputnu skaita samazināšanās cēloniem Engures ezerā [Observations on the causes of decrease of game waterfowl on the Lake Engure]. Latv. PSR ZA Vēstis, 1, 123-130 (in Latvian)

Mihelsons, H., Viksne, J., Mednis, A. (1976) The improvement of waterfowl nesting sites. In: International Conference on the cons. of wetlands and waterfowl. Heiligenhafen, VFR. 2-6 December 1974. Slimbridge, IWRB, pp. 345-348.

Oḷševskis, E., Liepin̄̌s, E. (2010). Rabies oral vaccination in Latvia — past, present and future. Grām.: Veterinārmedicīnas raksti. Starptautiskas zinātniskās konferences "Dzīvnieki. Veselība. Pārtikas higiēna" raksti. Jelgava. 169. 1pp.

Opermanis, O. (2002). Dedzināšana kā paṇēmiens aizsargājamo pḷavu putnu biotopa atjaunošanai [Burning as a tool to improve breeding habitat for meadow birds]. Grām.: Aktuāli savval̦as sugu un biotopu apsaimniekošanas piemēri Latvijā (28.-33. lpp.). Rīga (in Latvian).

Opermanis, O., Mednis, A., Bauga, I. (2001). Duck nests and predators: Interaction, specialisation and possible management. Wildlife Biol., 7, 87-96.
Opermanis, O., Mednis, A., Bauga, I. (2005). Assesment of compensatory predation and recolonization using long-term duck nest predator removal data. Acta Univ. Latviensis. Biology, 691, 17-30.

Scheffer, M., van Nes, E.H. (2007). Shallow lake theory revisited: Various alternative regimes driven by climate, nutrients, depth and lake size. Hydrobiologia. 584(1), 455-466.

Springe, G., Briede, A., Druvietis, I., Parele, E., Rodinovs, V., Urtāne, I. (1999). Investigations of biodiversity in freshwater ecosystems of Latvia. In: Hydrobiological Research in the Baltic Countries. Part 1. Rivers and Lakes (pp. 184-324). Volskis, R. (Ed.). Vilnius: Institute of Ecology.

Sprinǵe, G., Druvietis, I., Parele, E. (2000). The plankton and benthos communities of the lagoon lake Engures (Engure), Latvia. Proc. Latvian Acad. Sci. Sect. B, 5/6, 177-189.

Sprinğge, G., Briede, A., Druvietis, I., Grīnberga, L., Konošonoka, I., Parele, E., Rodinovs, V., Skuja, A. (2011). Long-term development of the hydroecosystem of the Lake Engure and its influencing factors. Proc. Latvian Acad. Sci., Section B, 65(5/6).

Spalis, D. (1999). Ūdensputni zvejnieku tỉklos Engures ezerā [Waterfowl in fishnets on Lake Engure. Putni dabā, 9(2), 20-21 (in Latvian).

Tauriņš, E. (1984). Plēsēji - Carnivora [Carnivores]. Grām.: Medības Latvijas PSR (31.-77. 1pp.). Rīga: Avots (in Latvian).

Transehe, N. (1937). Par Engures ezeru [About Lake Engure]. Daba un zinātne, 2, 33-40 (in Latvian).

Transehe, N. (1942). Das Vogelleben des Angernschen Sees. Korrespondenzblatt d. Naturf.-Ver. zu Riga. LXIV, Posen. 101-124.

Vermeer, K. (1968). Ecological aspects of ducks nesting in high densities among larids. The Wilson Bull., 80(1), 78-83.

Vīksne, J. (1997). The Bird Lake Engure. Rīga: Jāṇa sēta. 111 pp.

Vīksne, J. (2000). Changes of nesting bird fauna at the Engure Ramsar site, Latvia, during the last 50 years. Proc. Latvian Acad. Sci., Section B, 54, 5/6, 213-220.

Vīksne, J. (2009). Ūdensputnu medības klāt atkal... [Waterfowl hunting started again...]. MMD (Medības, Makšḳerēšana, Daba), 7, 14-16 (in Latvian).

Vīksne, J. (2010). Nomedītie... [Harvested...]. $M M D$, 8, 6-8 (in Latvian).

Vīksne, J., Janaus, M. (1989). Kaijveidīgo putnu un zivju gārṇu kolonijas Latvijā 1986. gadā [Colonies of gulls, terns and Grey Heron in Latvia in 1986]. Putni dabā, 2, 55-71 (in Latvian).

Vîksne, J., Janaus, M. (1993). What is going on with the Black-headed Gull (Larus ridibundus) at the eastern coast of the Baltic? Ring, 15(1-2), 154-158.

Vīksne, J., Mednis, A., Janaus, M. (2000). Breeding duck numbers and breeding success at two Latvian Ramsar sites, Lakes Engure and Kanieris, in 1999. OMPO Newsletter, 22, 25-39.

Vīksne, J., Mednis, A., Janaus, M., Stīpniece, A. (2005). Changes in the breeding bird fauna, waterbird populations in particular, on Lake Engure (Latvia) over the last 50 years. Acta Zoologica Lituanica, 15(2), 188-194.

Vīksne, J., Laubergs, A. (2007). Mākssīgās ligzdvietas meža pīlei [Artificial nest sites for Mallard]. Rīga: Latvijas Dabas fonds, 41 lpp. (in Latvian).

Wetzel, R.G. (1983). Lymnology. Saunders College Publishing. 878 pp.

Блум П.Н. (1973). Лыссуха (Fulica atra L.) в Латвии [The Coot (Fulica atra L.) in Latvia]. Рига: Зинатне. 155 с. (in Russian).

Вадзис Д.Р., Лине Р.Я., Сейсума З.К. (1976). Зоопланктон и макрозообентос в озерах Латвии [Zooplankton and macrozoobenthos in the lakes of Latvia]. Рига: Зинатне. 163 с. (in Russian)

Виксне Я.А. (1968). О структуре гнездовой популяции озерной чайки на приморских озерах Латвии [The structure of the nesting population of the Black-headed Gull (Larus ridibundus) on the coastal lakes of Latvia]. В кн.: Экология водоплавающих птии Латвии (с. 207-228). Рига: Зинатне (in Russian).

Виксне Я. (1981). Численность, распространение и демография озерной чайки (Larus ridibundus L.) в Латвии [The numbers, distribution and de- 
mography of the Latvian population of the Black-headed Gull]. Сообщ. Прибалт. ком. по изучению миграций птии (Тарту), 12, 95-115 (in Russian).

Виксне Я., Янаус М. (1986). Кормовые полеты озерной чайки оз. Энгурес [Feeding flights of the Black-headed Gull (Larus ridibundus) of the Engure Lake, Baltic]. Орнитология, 21, 31-37 (in Russian).

Виксне Я., Меднис А., Янаус М. (2001). Изменения численности озерной чайки и уток на озере Энгуре (Латвия) и их возможные причины [Changes of numbers of Black-headed Gull and ducks on the Lake Engure, Latvia, and its possible reasons]. В кн.: Aктуальные проблемы изучения и охраны птии Восточной Европь и Северной Азии. Мат. межд. конф. Респ. Татарстан (с. 141-142). Казань (in Russian).

Виксне Я., Меднис А., Блум П., Казубиернис Ю. (1989). Динамика численности гнездящихся уток, куликов и чайковых птиц орнитологического заказника озера Энгуре [Dynamics of numbers of breeding ducks, waders and Larids of the Engure Lake ornithological reserve in 1958-1982]. Сообщ. Прибалт. ком. по изучению миграций птии, (Тарту), 20, 36-45 (in Russian).

Меднис А.А. (1968). Влияние растительного покрова на видовой состав и размещение гнездящихся уток на островах озера Энгурес [Influence of vegetation on species composition and distribution of nesting ducks on islands of the Lake Engure]. В кн.: Экология водоплавающих птии Латвии (с. 71-83). Рига: Зинатне (in Russian).

Михельсон Г.А. (1961). О путях увеличения численности уток на ряде озер Латвийской ССР [Ways of increasing the numbers of nesting ducks on certain lakes of the Latvian SSR]. В кн.: Экология и миграции птии, Прибалтики (с. 57-70). Рига: Изд. АН Латвийской ССР (in Russian).
Михельсон Х.А., Леиньш Г.Т., Меднис А.А. (1968). Гнездящиеся утки озера Энгуре и их изучение [Nesting ducks of the Lake Engure and their investigation]. В кн.: Экология водоплавающих птии Латвии (с. 7-43). Рига: Зинатне (in Russian).

Михельсон Х.А., Меднис А.А., Блум П.Н. (1986). Популяиионная экология мигрирующих уток в Латвии [Population ecology of migratory ducks in Latvia]. Рига: Зинатне. 111 с. (in Russian).

Сабардина Г.С. (1968). Растительность островов - мест массового гнездования уток на озере Энгуре [Vegetation on the conservancy islands of Lake Engure]. В кн.: Экология водоплавающих птии Латвии (c. 45-69). Рига: Зинатне (in Russian).

Спурис З.Д. (1960). Лимнологическая характеристика озера Энгурес [Lymnological description of the Lake Engure]. В кн.: Рыбное хозяйство внутренних водоемов Латвийской ССР. V (c. 167-198). Рига: Изд. АН Латвийской ССР (in Russian).

Спурис 3.Д. (1962). Материалы по фауне ручейников озер Латвийской CCP [Materials on the caddis flies fauna on lakes of Latvian SSR]. Latvijas Entomologs, 6, 55-74 (in Russian).

Табака Л.В. (ред.) (1974). Флора и растительность Латвийской ССР. Приморская низменность [Flora and Vegetation of the Latvian SSR. Coastal Lowland]. Рига: Зинатне. 142 с. (in Russian).

Табака Л.В. (ред.) (1977). Флора и растительность Латвийской ССР. Курземский геоботанический район [Flora and Vegetation of the Latvian SSR. Kurzeme geobotanic region]. Рига: Зинатне. 142 с. (in Russian).

Янаус М. (1984). Состав добываемых на оз.Энгуре уток [Composition of ducks hunted on the Lake Engure]. Современное состояние ресурсов водоплавающих птиц (с. 275-277). Москва: Всесоюзный научноисследовательский институт охраны природы и заповедного дела МСX CCCP (in Russian).

Received 8 November 2011

\section{ENGURES EZERĀ (LATVIJA) LIGZDOJOŠOS ŪDENSPUTNUS IETEKMĒJOŠIE FAKTORI}

Engures ezers īpašu cilvēku uzmanību saistījis kopš 19. gadsimta vidus, kad ezera ūdens līmenis pazemināts, izveidojot jaunu noteci uz jūru tā ziemelu galā. Ezera platība samazinājās no apmēram $90 \mathrm{~km}^{2}$ līdz $45 \mathrm{~km}^{2}$, radās labvēlīgi apstākḷi virsūdens augāja attīstībai, kas šobrīd aizṇem 59\% no kopējās platības. Lieguma režīms ezerā noteikts, sākot ar 1957. gadu. Rakstā apkopoti galvenokārt publicēti Bioloğijas institūta Ornitoloǵijas laboratorijas dati, kas ievākti 1948.-2011. gadā. Aprakstīta klimata, cilvēka aktivitāšu, ūdens līmeṇa, augāja sukcesijas, antropogēnās un dabiskās barības, kā arī plēsonības ietekme uz ūdensputnu populācijām un uz ezera ekosistēmu kopumā. Parādītas dažādu ūdensputnu grupu (laucis, tārtinveidīgie, pīles, kaijveidīgie, dūkuri) savstarpējās attiecības. Demonstrēta augāja sukcesionālo pārmainu — plavu aizaugšana ar niedrēm un krūmiem, virsūdens augāja saplūšana lielos, niedru dominētos masīvos — negatīvā ietekme, samazinot ūdensputniem piemērotās platības. Parādīta antropogēnās barības loma lielā kīra populācijas augšanā un sekojošā sarukšanā, tās ietekme uz populācijām. Aprakstītas plēsonības struktūras pārmaiṇas laika gaitā. 